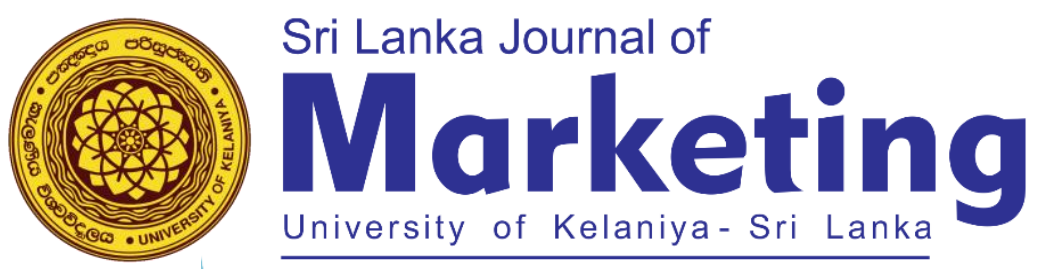

\title{
Impact of Social Media Advertising on Consumer Buying Behaviour: With Special Reference to Fast Fashion Industry
}

Bandara D. M. D.

Department of Marketing Management, University of Peradeniya, Sri Lanka darshana.bandara339@gmail.com

\section{ABSTRACT}

Recently, social media advertising has become a key component of the most successful fashion brands' marketing strategies. With the rise of social media, the majority of fashion retailers have started to identify the opportunities of using social media networks to attract new customers. The purpose of this study is to explore the impact of social media advertising on consumer buying behavior towards fast fashion. Along with the study, it measures the overall impact of social media advertising on the consumer decision making process in line with fast fashion industry.

This study adopts a descriptive quantitative research design and data was collected through selfadministrated questionnaire. The population of this study is taken from active social media users in Western province and a sample of 300 consumers was selected using the convenience sampling method. The hypotheses were tested using Correlation and Regression analysis since the purpose of the study is to measure the impact of each independent variable on the chosen dependent variable.

The present study revealed that social media advertising has a positive influence on consumer buying behavior towards the fast fashion industry. Three independent variables out of four, namely entertainment, familiarity, and social imaging, have a significant influence on consumer behavior, while the remaining variable, advertising expenditure, has no statistically significant influence. Also the study provides valuable implications for the fast fashion industry, allowing marketers to use the findings to identify their consumers' real buying behavior in a digital environment and make decisions accordingly.

Keywords: Consumer Buying Behavior, Fashion Retailers, Fast Fashion, Social Media Advertising 


\section{INTRODUCTION}

\subsection{Background of the Study}

As the emergence of social media advertising, most of the businesses have introduced their brands on social media platforms. At the initial stages, fashion retailers use social media to build awareness towards their brands, with the time most of the businessmen have recognized the importance of social media to reach their target customers, throughout the past decade, social media advertising has become much stronger. Also the previous studies convince that the development of social media advertising aligns with the fashion industry.

As an industry term the "fashion" could be characterized as a consumer behavioral phenomenon, surrounding both intangible and tangible contexts, within the domain of social influence and diffusion. Similarly the Fast fashion can be defined as cheap, trendy clothing that samples ideas from the catwalk or celebrity culture and turns them into garments in high street stores at breakneck speed. (Rauturier, 2018). In terms of fast fashion, it always bonded with the youth and trendiness Whereas fashion acts as a sign and aid to differentiate social identity, taste and cultural capital. (Watson, 2013) According to Kozinnets, Andrea, Sarah \& Valack, they found that both the social media and social media platforms contribute to every stage of the consumer decision making process model. Therefore, the "fashion conscious" people will be aware quicker than the others. "Traditional media such as printed media, radio, television advertising are replaced by social media advertising which has become an important channel of the marketing campaign" (Stephanie Agresta, 2010),

Considering the Sri Lankan fast fashion industry, they have gained a strong global reputation for the ethical production of high-quality apparel, such as Victoria's Secret, GAP, Liz Claiborne, Next, Jones New York, Nike, Tommy Hilfiger, Pink, Triumph, Ann Taylor, Marks \& Spencer, Boss etc. (EDB -Sri Lanka, 2019). Not only that there are some local Fashion chains like Nolimit and Odel introducing their own brands such as "NLM" and "Embark" similarly the other fashion brands like Kelly Felder, G flock. Doing their business in a different way, they are highly positioning their products into the upmarket Moreover, those companies are more focused on providing Sri Lankans with clothing that suits the local conditions, considering fashion industry now almost all the fashion chains do their maximum to capture the competitors' market, as a result of it, they use social media for their advertising campaigns. With that influence, Sri Lankan fashion retailers are in a silent war to attract consumers towards their brands

At the same time Gerald identified that the $71 \%$ of the social media users are more like to make purchases based on social media accounts, he also found that the millennials are considered to be the generation that spends most of their time online, with social media influencing $47 \%$ of their purchases. (Gerald, 2019) He further pointed out that social media provides a platform and the best way to execute an effective marketing campaign. 
Similarly, a recent report from Deloitte shows how social media advertising effects on consumer buying behavior And also it also states that $47 \%$ millennials are influenced by the social media (Roesler, 2019) There can be seen an ever more increasing impact of social media advertising on consumer buying behavior.

\subsection{Significance of the Study}

Study's findings provide valuable insights to fashion retailers regarding the current consumer buying behavioural patterns and the consumption patterns towards the fast fashion industry. Since the high competition in the industry, fashion retailers highly compete with each other, relatively they are spending thousands for advertising agencies to promote their brands, therefore they need to follow best practices to attract the consumers towards their brands, accordingly fashion retailers, marketing managers, brand managers in fast fashion industry benefited through the findings not only that general public also benefited through this by expanding their knowledge

\subsection{Research Problem}

As discussed above, many researchers have conducted to identify the relationship of the social media and the fashion industry. According to Gerald, he found that $47 \%$ of the purchases are influenced by the social media advertising, (Gerald, 2019) similarly the researcher Roesler found that the most of the people doing the online purchases are millennials (Roesler, 2019) going deep the researcher Preece uncovered some important findings related to the social media platforms and how they are working as the advertising tool, with that support he suggests to measure the impact of social media advertising towards on consumer behavioral change. Also, there is limited number of studies have been done on this area, to fill that gap further accordingly to fill the gap further investigations are needed in srilankan context.

Concerning the Srilankan fashion retailers, they wanted to know the real time insights about their customers and industry to grow their businesses, therefore further investigations are needed be done to find out most updated information regarding demographic factors ,social media consumption and consumer buying behavioral patterns of their consumers, on the other hand due to the high competition, Srilankan fashion retailers spend thousands on their social media advertising campaigns ,therefore the digital marketing firms and marketers need to identify their consumers' real buying behavior in a digital environment and make the decisions accordingly.

Based on the context, this study is going to find out the impact of social media advertising on consumer buying behavior with special reference to the fast fashion industry. 
The objectives of this research study can be listed as follows,

- To examine the different social media advertising types used in fashion industry.

- To analyze the level of impact of social media advertising on consumer buying behavior of fast fashion industry

- To identify the best practices of social media advertising to influence consumers in fast fashion industry

\section{LITERATURE REVIEW}

Considering the impact of social media on fashion industry, social media is playing a major role, within the past decade a remarkable development has been witnessed. Businesses are using social media as an advertising tool. Fashion industry is one of the businesses where frequent changes occur and social media is the most convenient and cheapest method to communicate. (Nawaz Ahmad,Atif Salman,Rubab Ashiq, 2015)The emergence of social media has transformed the world and its entire way of functioning, bringing the world and its people closer. Social media denotes activities, practices, and behaviors among clusters of people who gather online to share information, experiences and perspectives using colloquial media. Colloquial or conversational media are mainly online based applications that have enabled to create and transmit content in the form of words, pictures, videos and audios. (Brake D.K, 2009)The term fashion can be characterized as consumer behavioral phenomenon, surrounding both intangible and tangible contexts, within the domain of social influence

\subsection{Social Media and Consumer Buying Behaviour}

Studying online consumer behavior has become a major factor for scholars and researchers to understand what motivates retail consumers to shop, thus leading to enhance customer satisfaction and retail performance, (Puccinelli, 2009)Web and virtual social media have revolutionized consumers buying behavior with worldwide connection through information by superior social networking and intensified communication capacity (Ioanas, 2014), further all recent studies found that consumer behavior and buying behavior were strongly influenced by social media ,personal trust, online communication and online searching attitudes of consumers moreover it has been noticed that Facebook and Instagram had a great influence on the consumer behavior because that provide opportunity for consumers to interact and communicate with peers to share their opinion on products. (Ioanas, 2014) So for marketers, it is important to understand how this demographic consumes information and second, how to deliver the right marketing message that appeals to them (Johnson, 2014) 


\subsubsection{Entertainment}

Entertainment has been one of the key criteria for advertisement creation. Similarly, Entertainment is used as a method to draw customer attention. Customers are more likely to recall an interesting and exciting commercial, rather than a dull one. In addition, it can be assumed that entertainment improves advertising effectiveness. That is why many businesses spend a lot of money to make humorous commercials (Mandan, 2013).

Entertainment is an important and pervasive element of television ads. Most ads today have at least one form of content used to entertain the consumer, such as humor, creative stories, or upbeat music. Recently, advertisers have been attempting to create ads with ever - increasing levels of entertainment (Paul R. La Monica, 2007) further, it impacts purchase intentions directly through a persuasion mechanism and indirectly by increasing viewing interest through the ad's attractiveness The more entertainment in the ad, the more attractive it is .

\subsubsection{Familiarity}

According to Alba \& Hutchison familiarity is the number of products related or service related experiences gathered by the consumer. These related experiences include direct and indirect experiences such as exposure to advertisements, interactions with salespersons, word of mouth contact, trial and consumption. (Alba \& Hutchinson, J.W., 1987)Since people frequently look for specific objects or a collection of items in real-life environments, visual searching is the most investigated activity. (Geisler, W. S. \& Cormack, L. K.,, 2011)

When conducting visual search studies, participants look for a target object among distracting objects (Wolfe, 2004) suggest that familiarity may deliver a positive impression of a service or an object. Similarly, brand familiarity is identified as the accumulated correlated experiences that customers have had with a brand (Ballester, Navarro \& Sicilia, 2012).

\subsubsection{Social Imaging}

In general advertisements show how people perceive things around. Specially some specific ads represent how a user of a specific product is, or should be. Often it reveals the social class to which the user of a product belongs, its lifestyle and attitudes. This definition is highly applicable in case of beauty products. (Tashrifa Haider \& Shadman Shakib, 2017) Further Prior studies have shown that stereotyping and classification of a certain gender or group of people has a huge impact on the mass population. To emphasize the impact on social imaging now businesses using influential marketing attract consumer businesses using celebrity people for their advertisements. In digital context they are simply known as "social media influencers" (Newberry, 2019). 


\subsubsection{Advertisement Spending}

Heavy advertising spending indicates that the company is investing in the brand, which means that the company has a large investment and thus suggests a higher product quality (Kirmani \& Wright, 1989). The earlier studies have concluded that when a huge sum is spent on advertisements and other marketing campaigns consumers began to expect more from that particular brand. It creates and illusion of better quality of a product or service from that brand (Haider \& Shakib, 2017). Moreover, global landscape of advertising shows a huge development throughout the past few years, it is estimated that advertising spending worldwide will surpass 560 billion U.S. dollars in 2019, representing a growth of roughly four percent compared with the previous year (Guttmann, 2019).

\subsubsection{Impact of Social Media on Consumer Buying Behaviour}

Concerning the literature, it shows that there have been many studies conducted, focusing on social media and the fast fashion industry. Yet only few studies are found that are focused on the impact of social media advertising on consumer buying behavior. In 2013, Kumar and Raju published their research paper on "The Role of Advertising in Consumer Decision Making". In their study, they have found that advertisements are capable of changing consumer opinion on particular products. (D.P Kumar \& K.V Raju , 2013), Furthermore, the primary objective of advertisement could be identified as making an impact on the consumer buying behavior.

Most of the time, consumer buying behavior is influenced by liking or disliking of consumer towards the advertisement of the product advertised (Smith et al, 2006). It can therefore be said that the consumer behavior towards a product is entirely depending on advertising, without any consideration of the features of the product. In 2017, Tashrifa Haider \& Shadman Shakib have identified the impact of social media advertising on consumer buying behavior. In their study, they have identified four independent variables of social media advertising that makes an impact on consumer buying behavior, which are Entertainment, Familiarity, Social Imaging and Advertisement spending (Haider \& Shakib, 2017). The researcher used this model as the conceptual framework of the study. 


\section{CONCEPTUAL FRAMEWORK}

Figure 1: Conceptual Framework:

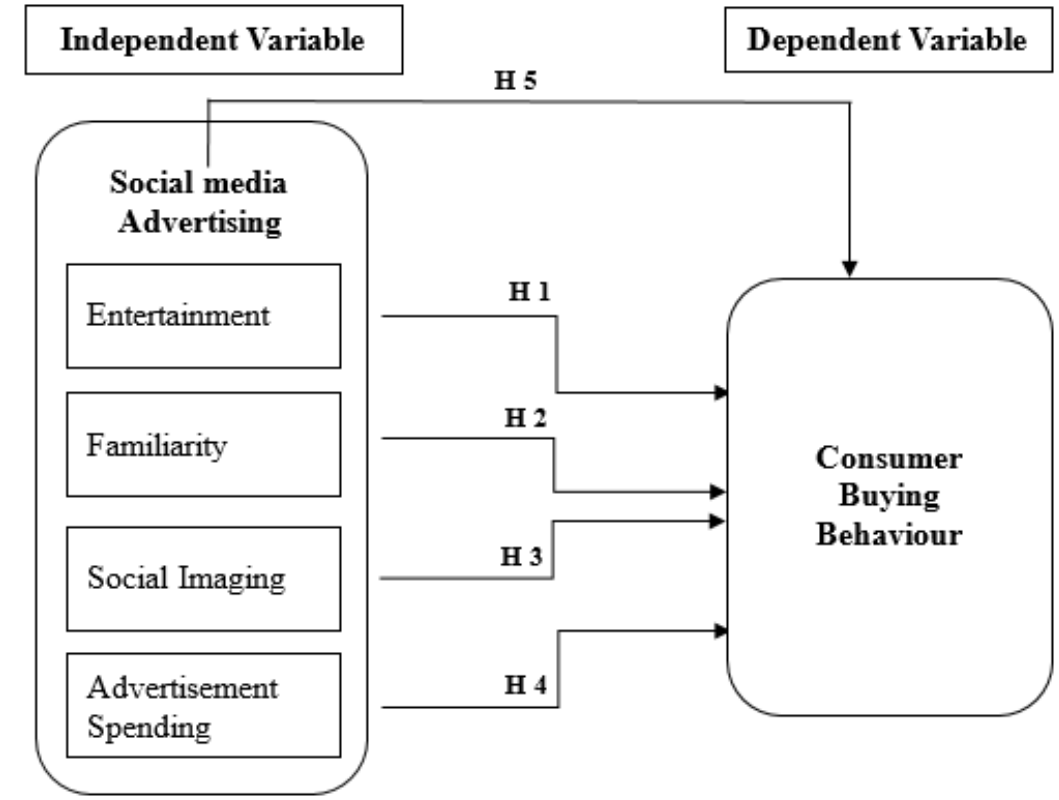

Source: (Haider \& Shakib, 2017)

\subsection{Hypotheses}

The researcher has developed following hypotheses based on the theoretical model.

- H 1: Consumer's buying behavior is positively influenced by Entertainment factor of the social media advertising campaign.

- H 2: Consumer's buying behavior is positively influenced by Familiarity factor of the social media advertising campaign.

- H 3: Consumer's buying behavior is positively influenced by Social Imaging factor of social media advertising campaigns.

- H 4: Consumer's buying behavior is positively influenced by the amount that is spent in social media advertising campaign.

- H5: Consumer buying behavior is positively influenced by Social Media Advertising

\section{METHODOLOGY}

\subsection{Research Design}

Research design explains the total structure of the research methodology and it contains the Research philosophy, Research approach, Research strategy and time horizon and techniques and procedures Research philosophy of the study can be identified under positivistic, epistemological, assumption 
through the research therefore the researcher is separated from the study. Deductive research approach will conduct on the study that means research is focused to test existing theory.

Research strategy identified as the "Survey" which means research used questionnaires to collect the research data time horizon of the study can be selected as one-shot/ cross-sectional which means data were gathered only one time.

\subsection{Population and Sample}

Population is the entire group of people that the researcher wishes to investigate. In other words, the population includes all the elements of the study. According to the mid-year population estimates made by department of census and statistics Study population is selected from the western province, which represents the highest population of Sri Lanka. The Study population is confined to the western province, which consisted of Colombo, Gampaha and Kaluthara districts collectively $28 \%$ of the total population of Sri Lanka which is 6,149,000 (Department of Census \& Statsitics , 2019)., Study undertakes the target population as fashion conscious and active social media users live within the western province, Data were gathered from the sample of 300 consumers of the population using the convenience sampling method.

\subsection{Data collection method}

The primary data source of this research was mainly obtained from the questionnaires Therefore, questionnaires were distributed both offline and online to the target respondents, secondary data were gathered by referring the previous studies and other secondary information sources.

\subsection{Data Presentation and Analysis}

As the study is more quantitative oriented collected data will be analyzed using an analyzing software named "Statistical Packages for Social Sciences (SPSS-26)"., it contains, Assumption testing, correlation analysis, regression analysis in both simple linear and multiple linear methods in order to test the hypotheses.

\section{DATA ANALYSIS AND DISCUSSION}

\subsection{Descriptive Statistics}

Descriptive statistics were used to explain and interpret the basic characteristics of the data.

Table 1: Descriptive Statistics

\begin{tabular}{|l|l|l|l|l|l|}
\hline & Entertainment & Familiarity & $\begin{array}{l}\text { Social } \\
\text { Imaging }\end{array}$ & $\begin{array}{l}\text { Advertisement } \\
\text { Spending }\end{array}$ & $\begin{array}{l}\text { Consumer } \\
\text { Buying } \\
\text { Behaviour }\end{array}$ \\
\hline Mean & 2.9908 & 3.1511 & 3.0167 & 2.8133 & 3.0813 \\
\hline Median & 3 & 3 & 3 & 3 & 3 \\
\hline
\end{tabular}




\begin{tabular}{|l|l|l|l|l|l|}
\hline Mode & 3.25 & 2.33 & 3.2 & 3.33 & 3 \\
\hline Std. Deviation & 0.799 & 0.847 & 0.754 & 0.872 & 0.733 \\
\hline Variance & 0.639 & 0.719 & 0.569 & 0.761 & 0.539 \\
\hline Skewness & 0.009 & 0.326 & 0.011 & 0.01 & 0.013 \\
\hline
\end{tabular}

Source: Survey Data, 2019

According to the table 1 mean value of the variables; Entertainment, Familiarity, Social Imaging and Advertisement Spending and Consumer Buying behaviour respectively state 2.99, 3.15,3.01,2.81 and 3.08 which have dispersed from the mean values amounting $0.799,0.847,0.754,0.872,0.733$ of standard deviations lay at the acceptable range.

\subsection{Reliability Test}

Considering the dependent and independent variables, Consumer Buying behavior, Entertainment, Familiarity, Social Imaging and Advertisement Spending, respectively state 0.866,0.934,0.871,0.856, 0.768 of Cronbach's Alpha values and all of those values are greater than 0.7. Therefore, the extent to which the questionnaire of this study remains the same, and the questionnaire or the measurement continue to be stable over time and the similarity of measurements within a given time period is ensured.

Table 2: Reliability Analysis

\begin{tabular}{|c|c|c|}
\hline & Cronbach's Alpha & N of Items \\
\hline Consumer Buying Behaviour & 0.866 & 5 \\
\hline Entertainment & 0.934 & 4 \\
\hline Familiarity & 0.871 & 3 \\
\hline Social Imaging & 0.856 & 5 \\
\hline Advertisement Spending & 0.768 & 3 \\
\hline
\end{tabular}

(Source: Survey Data, 2019)

\subsection{Assumption Testing}

\subsubsection{Normality Test}

Figure 1 : Normal Probability Plot

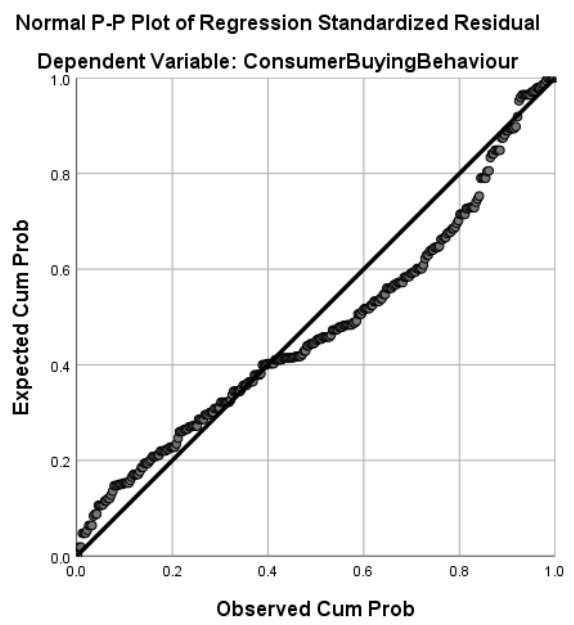

(Source: Survey Data, 2019) 
Normality derives from the normal distribution which is a key concept of statistics in practice, according to the below normal probability plot it can be assumed that most of the dots were close to the normality line. Thus, it can be concluded that the dataset is normally distributed.

\subsubsection{Multi-collinearity Analysis}

Table 3: Multi-collinearity Analysis

\begin{tabular}{|l|l|l|}
\hline & $\begin{array}{l}\text { Collinearity Statistics } \\
\text { Tolerance }\end{array}$ & $\begin{array}{l}\text { Statistics } \\
\text { VIF }\end{array}$ \\
\hline Entertainment & 0.148 & 6.745 \\
\hline Familiarity & 0.436 & 2.295 \\
\hline Social Imaging & 0.128 & 7.784 \\
\hline Advertisement Spending & 0.689 & 1.451 \\
\hline
\end{tabular}

(Source: Survey Data, 2019)

According to Weisberg \& Britt state that anything under 0.20 tolerances and exceeds 10 of VIF value suggests serious multi-collinearity in a model. (Weisburd, D. \& Britt, C., 2013) Here Entertainment and social Imaging Indicates a value under 0.20 and all the other independent variables exceed 0.20 of tolerance level and all the VIF values reported lesser than 10, thus it can conclude it's nearly full fill the conditions.

\subsubsection{Linearity}

Table 4: Linearity Table

\begin{tabular}{|l|l|}
\hline $\mathbf{R}^{2}$ linearity value \\
\hline Entertainment & 0.853 \\
\hline Familiarity & 0.762 \\
\hline Social Imaging & 0.864 \\
\hline Advertisement Spending & 0.318 \\
\hline
\end{tabular}

(Source: Survey Data, 2019)

According to the above table 4, values taken from the linearity graphs shows the majority of the dots lie along with linear line therefore, it can conclude that there is linear relationship between separate independent variables and the dependent variable. 


\subsubsection{Homoscedasticity}

Figure 2: Homoscedasticity

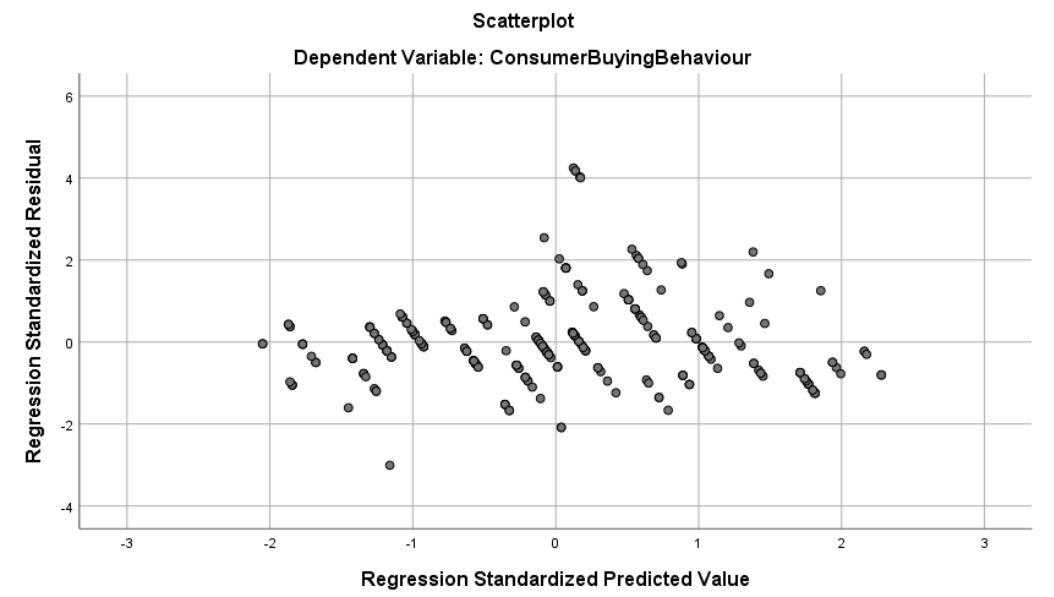

(Source: Survey Data, 2019)

Scatter plot indicates a random array of dots around the regression line Thus, all independent variables showed no obvious signs of funneling, therefore it can be concluded that the assumption of homoscedasticity has been met.

\subsection{Correlation Analysis}

According to the table 5 the Pearson's correlation values with respect to each independent variable, Entertainment, Familiarity, Social Imaging, Advertisement spending, reported a correlation values of $0.924,0.873,0.929$, and 0.564 respectively.

\section{Table 5: Correlation Analysis}

\begin{tabular}{|l|c|c|c|c|c|c|}
\hline $\begin{array}{l}* * \text { Correlation is } \\
\text { significant at the 0.01 } \\
\text { level (2-tailed). }\end{array}$ & $\begin{array}{l}\text { Consumer } \\
\text { Buying } \\
\text { Behavior }\end{array}$ & Entertainment & Familiarity & $\begin{array}{l}\text { Social } \\
\text { Imaging }\end{array}$ & $\begin{array}{l}\text { Advertisement } \\
\text { Spending }\end{array}$ & $\begin{array}{l}\text { Sig. (2- } \\
\text { tailed) }\end{array}$ \\
\hline $\begin{array}{l}\text { Consumer Buying } \\
\text { Behavior }\end{array}$ & 1 & $.924^{* *}$ & $.873^{* *}$ & $.929^{* *}$ & $.564^{* *}$ & 0.000 \\
\hline Entertainment & $.924^{* *}$ & 1 & $.711^{* *}$ & $.922^{* *}$ & $.516^{* *}$ & 0.000 \\
\hline Familiarity & $.873^{* *}$ & $.711^{* *}$ & 1 & $.746^{* *}$ & $.468^{* *}$ & 0.000 \\
\hline Social Imaging & $.929^{* *}$ & $.922^{* *}$ & $.746^{* *}$ & 1 & $.551^{* *}$ & 0.000 \\
\hline Advertisement Spending & $.564^{* *}$ & $.516^{* *}$ & $.468^{* *}$ & $.551^{* *}$ & 1 & 0.000 \\
\hline
\end{tabular}

(Source: Survey Data, 2019) 


\subsection{Regression Analysis}

\subsubsection{Model Summary}

Table 6: Model Summary

\begin{tabular}{|c|c|c|c|c|c|c|c|c|c|}
\hline \multirow[b]{2}{*}{ Model } & \multirow[b]{2}{*}{$\mathrm{R}$} & \multirow[b]{2}{*}{ R Square } & \multirow[b]{2}{*}{$\begin{array}{l}\text { Adjusted R } \\
\text { Square }\end{array}$} & \multirow{2}{*}{$\begin{array}{l}\text { Std. Error } \\
\text { of the } \\
\text { Estimate }\end{array}$} & \multicolumn{5}{|c|}{ Change Statistics } \\
\hline & & & & & $\begin{array}{l}\text { R Square } \\
\text { Change }\end{array}$ & F Change & df1 & df 2 & $\begin{array}{l}\text { Sig. F } \\
\text { Change }\end{array}$ \\
\hline 1 & $.980^{\mathrm{a}}$ & 0.960 & 0.959 & 0.14832 & 0.960 & 1756.472 & 4 & 295 & 0.000 \\
\hline
\end{tabular}

(Source: Survey Data, 2019)

R Square represents the Coefficient of Determination which measures the proportion of variation in one variable that is explained by the other. $\mathrm{R}$ square of the model is obtained as 0.960 Hence it can be identified that $4 \%$ of unexplained variations are involved in the model. Therefore, $96 \%$ of the dependent variable can be explained from the independent variables; Entertainment, Familiarity, Social Imaging and Advertisement Spending.

\subsubsection{ANOVA}

Table 7: ANOVA

\begin{tabular}{|l|l|l|l|l|l|l|}
\hline Model & & Sum of Squares & df & Mean Square & F & Sig. \\
\hline 1 & Regression & 154.566 & 4 & 38.641 & 1756.472 & $.000^{\mathrm{b}}$ \\
\hline & Residual & 6.490 & 295 & 0.022 & & \\
\hline & Total & 161.055 & 299 & & & \\
\hline
\end{tabular}

(Source: Survey Data, 2019)

According to the above table 7 it depicts, $\mathrm{P}$ value is 0.000 , which is less than 0.05 . It illustrates that the overall model applied can be statistically significant and predicts the dependent variable. Further table revealed that out of total 161.055 of the sum of square, 154.566 of variation can be explained by regression where 6.490 of variation of dependent variable consumers' buying behavior is explained by the residual. Thus, it can be concluded that the model is fitted because a relatively large portion is explained by regression.

\subsubsection{Coefficients}

Table 8: Coefficients Multiple Regression

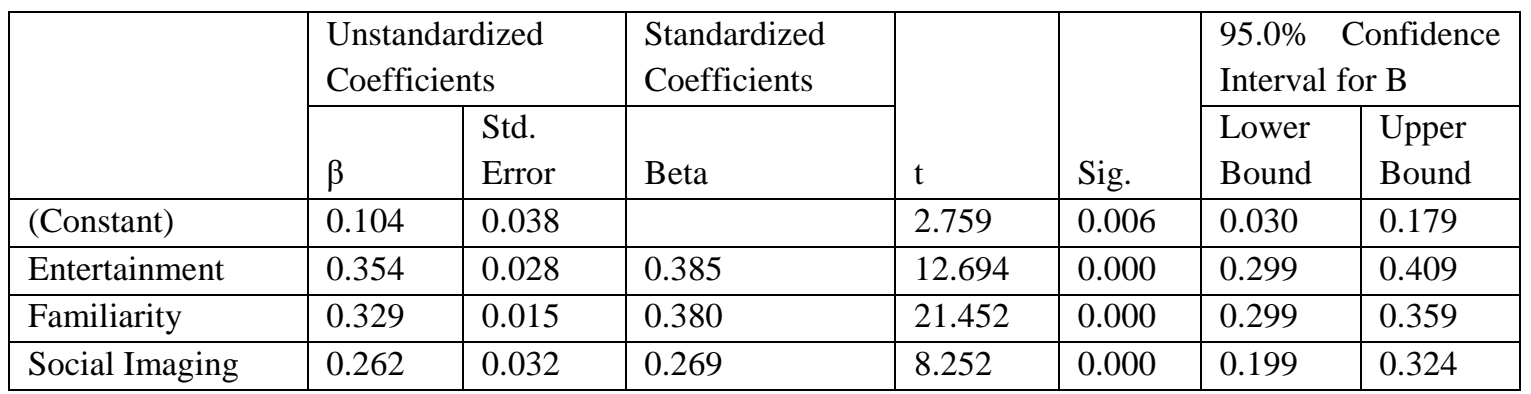




\begin{tabular}{|l|l|l|l|l|l|l|l|l|l|}
$\begin{array}{l}\text { Advertisement } \\
\text { Spending }\end{array}$ & 0.033 & 0.012 & 0.039 & 2.796 & 0.006 & 0.010 & 0.056 \\
\hline
\end{tabular}

(Source: Survey Data, 2019)

According to the table 8 it depicts the beta $(\beta)$ and significance (p) values with respect to each independent variable towards the consumer buying - behavior, Entertainment $(\beta=0.354, \mathrm{P}=0.000)$, Familiarity $(\beta=0.329, P=0.000)$, Social Imaging $(\beta=0.262, P=0.000)$, Advertisement spending $(\beta=$ $0.033, \mathrm{P}=0.006$ ), all the independent variables indicate positive values and all the significance values lie on the accepted range that is $\mathrm{P}<0.05$ therefore, it can be concluded that social media advertising indicates a significant positive relationship towards the dependent variable consumer buying behaviour. Therefore, the regression model can articulate as follows.

$$
\hat{\mathrm{Y}}=\alpha+\beta 1 \mathrm{X} 1+\beta 2 \mathrm{X} 2+\beta 3 \mathrm{X} 3+\epsilon
$$

$\hat{\mathrm{Y}} \quad=$ Dependent variable $=$ Consumer Buying Behaviour $(\mathrm{CBB})$

$\mathrm{X} 1=$ Independent Variable $1=$ Entertainment $(\mathrm{EN})$

$\mathrm{X} 2=$ Independent Variable $2=$ Familiarity (FA)

$\mathrm{X} 3=$ Independent Variable $3=$ Social Imaging $(\mathrm{SI})$

$\mathrm{X} 4=$ Independent Variable $4=$ Advertisement Spending (AS)

$\alpha \quad=$ constant value

$€ \quad=$ Error

$\beta 1, \beta 2, \beta 3 \ldots$ represent the Coefficients

Formula 1 : Regression Model

$$
\begin{aligned}
& \hat{Y}=0.104+0.354 \mathrm{X} 1+0.329 \mathrm{X} 2+0.262 \mathrm{X} 3+0.033 \mathrm{X} 4+\varepsilon \\
& \mathrm{CBB}=0.104+0.354 \mathrm{EN}+0.329 \mathrm{FA}+0.262 \mathrm{SI}+0.033 \mathrm{AS}+\varepsilon
\end{aligned}
$$

\subsection{Hypotheses Testing}

In order to test the hypotheses of the current study, linear regression and multiple regression analyses were adopted. The Hypothesis can be tested using R, R Square P - value (sig level) and the Coefficient (B); therefore, $\mathrm{R}$ and $\mathrm{R}$ square results taken from simple linear regression tables and coefficient values have taken from the multiple linear regression tables. Below table 9 depicts the summary results of regression analyses. 
Table 9: Summary of Hypotheses Testing

\begin{tabular}{|c|c|c|c|}
\hline Hypothesis & Relationship & Status & Justification \\
\hline $\mathrm{H} 1$ & Positive Significant & Accepted & $\begin{array}{l}\mathrm{R}=0.924 \\
\mathrm{R} \text { Square }=0.853 \\
\mathrm{P} \text {-value }=0.000 \\
\text { Coefficient }=0.354\end{array}$ \\
\hline $\mathrm{H} 2$ & Positive Significant & Accepted & $\begin{array}{l}\mathrm{R}=0.873 \\
\mathrm{R} \text { Square }=0.762 \\
\mathrm{P} \text {-value }=0.000 \\
\text { Coefficient }=0.329\end{array}$ \\
\hline H3 & Positive Significant & Accepted & $\begin{array}{l}\mathrm{R}=0.929 \\
\mathrm{R} \text { Square }=0.864 \\
\mathrm{P} \text {-value }=0.000 \\
\text { Coefficient }=0.262\end{array}$ \\
\hline $\mathrm{H} 4$ & Positive Significant & Accepted & $\begin{array}{l}\mathrm{R}=0.564 \\
\mathrm{R} \text { Square }=0.318 \\
\mathrm{P} \text {-value }=0.000 \\
\text { Coefficient }=0.033\end{array}$ \\
\hline H5 & Positive Significant & Accepted & $\begin{array}{l}\mathrm{R}=0.980 \\
\mathrm{R} \text { Square }=0.960 \\
\mathrm{P} \text {-value }=0.000 \\
\mathrm{CBB}=0.104+0.354 \mathrm{EN}+0.329 \mathrm{FA}+0.262 \mathrm{SI}+ \\
0.033 \mathrm{AS}+\varepsilon\end{array}$ \\
\hline
\end{tabular}

(Source: Survey Data, 2019)

Testing the H5, it can measure the collective impact of all Independent variables towards the dependent variable, which means impact of social media advertising on consumer buying behaviour, as per the findings, $\mathrm{R}=0.980, \mathrm{R}$ Square $=0.960 \mathrm{P}$-value $=0.000$, from $0.960 \mathrm{R}$ Square value it shows the collective impact of social media advertising which, if the social media advertising increase by 1 unit the Consumer Buying behaviour increases by of $0.960(96 \%)$. Also the P-value of the Social Media advertising Indicates 0.000 which is less than 0.05 level of significance and therefore there is a significant positive relationship between Social media advertising and Consumer buying behaviour, further it can be justify using following regression model.

$$
\begin{aligned}
& \mathrm{Y}=0.104+0.354 \mathrm{X} 1+0.329 \mathrm{X} 2+0.262 \mathrm{X} 3+0.033 \mathrm{X} 4+\varepsilon \\
& \mathrm{CBB}=0.104+0.354 \mathrm{EN}+0.329 \mathrm{FA}+0.262 \mathrm{SI}+0.033 \mathrm{AS}+\varepsilon
\end{aligned}
$$

\subsection{Summary of Key Findings}

According to the descriptive statistics of demographic variables it can be found almost all the respondents have their interest on in fast fashion. 59\% from the whole sample represented by females. Majority of the respondents' age lie between 21-30 age on results, which is categorized as young adults. Analyzing the social media presence of the sample, $87 \%$ of respondents indicate that there are following fashion brands online. 
Entertainment, Familiarity, Social Imaging and Advertisement Spending Separately state 0.924, 0.873, 0.929, 0.564 of Pearson Correlation values towards the consumer buying behavior, Therefore Social Imaging and Entertainment factors state the highest correlation with the dependent variable consumer buying behaviour whereas advertisement spending states the moderate correlation.

According to table 9, $\beta$ coefficient of the Entertainment indicates 0.354 . if the Entertainment increases by one unit while other variables are constant, the Consumer Buying behavior increases by 0.354 (35.4\%), Similarly the familiarity depicts $\beta$ value of 0.329 , It illustrates if the Familiarity increase by one unit while other variables are constant, the Consumer Buying behavior increases by 0.329 (32.9\%). $\beta$ value of Social Imaging indicates 0.262 , if the Social Imaging increases by one unit while other variables are constant, the Consumer- Buying behavior increases by 0.262 (26. 2\%). Whereas Advertisement Spending Indicates beta value of 0.033 and it Illustrates if the Advertisement Spending increase by one unit while other variables are constant, the Consumer Buying behavior increases by 0.033 (3. 3\%).Also the P-value of the variables states that less than 0.05 level of significance, which implies a significance relationship, that can conclude all the hypotheses of the study have been accepted.

\section{CONCLUSION AND RECOMMENDATIONS}

\subsection{Managerial Implications}

Constructing the managerial implications of the study, it depicts a more realistic and practical implications, therefore the fashion industry retailers can use this study to change the consumers buying behavior towards their brand, also findings of the study can directly apply on fast the fashion industry itself. Hence, the study provides the following recommendations.

In practice, fashion retailers use more attractive advertising campaigns to develop their brands, from those advertisements fashion retailers can influence people to purchase their brand, which means they using advertising to make a positive impact on the consumers' buying behavior therefore, the fashion retailers need to think of innovative ways of getting their consumers.

The Present study found that the most suitable advertising types for change consumer buying behavior are entertainment, Familiarity, Social Imaging and advertisement spending, assume that the fashion retailer uses social imaging in their social media campaign that means fashion retailer uses an influencer such as a celebrity to endorse the fashion brand, after exposing to the advertisement people try to follow that personality and accordingly people think of purchasing the product. Therefore, indicators of social imaging can be identified as Customer Image and Superiority, which means Social class that shows in advertisement will increase customer image towards fashion brands and social imaging shows the superiority. When competing with other fashion brands therefore, that can conclude social imaging has a positive impact on consumer buying behaviour. Similarly, all the other variables of study have 
statistically proved the positive impact on consumer buying behavior, therefore it is recommended to adopt to Entertainment, Familiarity, Social Imaging and Advertising spending to develop the campaigns.

\subsection{Areas for Future Research}

The fashion industry may change in the wake of cultural influences. Therefore, future researchers need to focus on cross-cultural aspects. This study is focused only on the overall impact that social media advertising is making on consumer's decision making process. In consequence, future researchers need to measure the impact on of each element of the decision making process. Moreover, the study used survey as the data collection method and it may create limitations because some questions can confuse the respondents and they can be refused to answer. Therefore, adaption of questions to uncover deeper emotional influencers would be recommended for future research. Considering the study, it was basically conducted on the quantitative aspect. Thus it would be more apprehensive to conduct both the qualitative and quantitative research method that can generate more useful insights

\subsection{Limitations}

- Measuring the impact of social media advertising on consumer buying behavior, it is limited only to fashion industry, therefore generalizing the findings need further investigations for the other contexts.

- Sample size of the study is limited only to 300 respondents, that might not be capable of getting accurate outcome from large population.

- Geographical area of the research will be limited only to the western province; therefore, generalizing the results need further investigations.

- Since the convenience sampling technique used researcher's biases can be found, therefore that can be identified as the limitation of the study.

\subsection{Conclusion}

This study was conducted to measure the impact of social media advertising on consumer buying behavior: special reference to the fast fashion industry. Gathered data were analyzed using descriptive and inferential statistics. Therefore, findings of the regression analysis show that the independent variables of the study; Entertainment, Familiarity, Social Imaging, and advertisement spending, significant positive significant impact on dependent variable, consumer buying behavior, therefore all the four hypotheses of study were accepted. Implications of the study provide a source of knowledge to Fashion Retailers and marketers. Similarly, study contributes as a source of literature to the future researchers. 


\section{REFERENCES}

A. Guttmann -Statista analyser . (2019, 07 09). Global advertising spending from 2010 to 2019 (in billion U.S. dollars). Retrieved from www.statista.com: https://www.statista.com/statistics/236943/global-advertisingspending/

Alba \& Hutchinson, J.W. (1987). Dimensions of consumer expertise. Journal of Consumer Research,, 411-454.

Azeen Ghorayshi. (2012). Quick Reads: “Overdressed” by Elizabeth Cline.

Ballester, E.D., Navarro, A. \& Sicilia, M. (2012). Revitalising brands through communication messages. The role of brand familiarity. European Journal of Marketing 46(1/2), 31-51.

Brake D.K. (2009). The social media bible, tactics, tools \& strategies for business success. John Wiley \& Sons,.

D.P Kumar \& K.V Raju . (2013). The Role of Advertising in Consumer Decision Making. IOSR Journal of Business and Management (IOSR-JBM), 37-45.

Department of Census \& Statsitics . (2019, 18 01). www.statistics.gov.lk. Retrieved from Department of Census \& Statsitics : http://www.statistics.gov.lk/

Di Pietro, L. \&. (2012). An Empirical Investigation of Social Network influence on consumer purchasing decision: The case of Facebook. Journal of Direct, Data and Digital Marketing Practice, 18-29.

Dorado, L. (2011). The Effect of Social Media on the Fashion Retail Industry. South Carolina: Elon University.

EDB -Sri Lanka. (2019, 12). www.srilankabusiness.com. Retrieved from Export Develoment Board : https://www.srilankabusiness.com/apparel/about/

"Fast fashion" ,Merriam-Webster. (2019, 6 26). Retrieved from Merriam-Webster.com.: https://www.merriamwebster.com/dictionary/fast\%20fashion

Geisler, W. S. \& Cormack, L. K.,. (2011). Models of overt attention. In: S. P. Liversedge, I. D. Gilchrist and S. Everling,. In The Oxford handbook of eye movements. Oxford University Press.

Gerald, R. F. (2019, 11 29). connextdigital. Retrieved from How Does Social Media Impact Consumer Buying Behavior: https://connextdigital.com/how-social-media-impact-consumer-buying-behavior/

H.McCormick et al, J. P. (2014). Fashion retailing-past, present and future. Textile Progress. 227-321.

Heinonen, k. (2011). Manegerial approces to consumerswsocial media behaviour. Journal of consumer Behaviour, 356-364.

Ioanas, E. \&. (2014). Social Media and Its Impact on Consumers' Behavior. International Journal of Economic Practices and Theories, 295-303.

Johnson, W. (2014). What's the Biggest Influencer in Consumer Purchase Decisions? Retrieved from www.smallbiztrends.com: https://smallbiztrends.com/2014/10/influence-consumer-purchase-decisions.html

Kozinnets .Andrea Sarah \& Valack . (2010). Networked narratives. Journal of Marketing.

Mandan, M. H. (2013). Investigating the impact of advertising on customer's behavioural intentions. Business and Economic Research.

Moher. (2013). The Impact of Social Media on The Fashion Industry. Journal of Applied Business \& Economics. $15(2), 17-22$. 
Muhammad Shafiq, Hamid Shahzad and Muhammad Imran Khan. (2014). The relationship of social media with fashion consciousness and.

Nawaz Ahmad,Atif Salman,Rubab Ashiq. (2015). The Impact of Social Media on Fashion Industry: Empirical. ISSN 2422-8397 An International Peer-reviewed Journal.

Neil M. Coe et al, H. W.-C. (2015). Gloabl Production networks. OXFORD university press.

Newberry, C. (2019, 05 02). Influencer Marketing in 2019: How to Work With Social Media Influencers. Retrieved from blog.hootsuite.com: https://blog.hootsuite.com/influencer-marketing/

Paul R. La Monica. (2007, 03 21). The Problem with TV ads. Retrieved from http://money.cnn.com:

Preece, H. (2012). Examining Social Media Use in Fashion: the Need for Industry Standards. t. California: Polytechnic University.

Puccinelli, N. M. (2009). Customer experience management in retailing: understanding the buying process. Journal of retailing, 15-30.

Rauturier, S. (2018, 08 07). In The Know. Retrieved from https://goodonyou.eco/what-is-fast-fashion/

Roesler, P. (2019). How social media influences consumer buying decisions. bizjournals.

Smith et al, E. a. (2006). Effects of Advertising Likeability: A 10Year Perspective. Journal of Advertising Research - JAR.

Stephanie Agresta, B. B. (2010). Perspectives on Social Media Marketing.

Tashrifa Haider \& Shadman Shakib. (2017). A Study On The Influences of Advertisement On Consumer Buying Behavior. Business Studies Journal.

Terrell, E. (2012). Fashion Industry: A Resource Guide. Retrieved from https://guides.loc.gov/fashion-industry

Watson, M. A. (2013). An exploratory study of the decision processes of fast. Journal of Fashion Marketing and Management: An International, 141-159.

Weisburd, D. \& Britt, C. (2013). Statistics in Criminal Justice. Springer Science \& Business Media.

Wilson, Eric. (2017, 2 21). Retrieved from https://fashion-history.lovetoknow.com/fashion-clothingindustry/evolution-fashion-industry

Wolfe, J. M. (2004). What attributes guide the development of visual attention and how do they do it? Nature Reviews Neuroscience, [e-journal]. 